\title{
OS PROTAGONISMOS DO CRUEL E DO CRU, ANTES DOS “FAVORITOS” DE FERNÃO LOPES E PERO LOPEZ DE AYALA
}

\author{
The protagonisms of Pedro the Cruel and Pedro I before \\ Fernão Lopes's and Pero Lopez de Ayala's "favorites"
}

Marcella Lopes Guimarães*

\begin{abstract}
RESUMO
Não é possível ignorar a matéria referente a Castela na Crônica de D.Pedro de Fernão Lopes. A fonte principal do cronista português foi o texto de Pero Lopez de Ayala mas, assim como Lopes foi funcionário da nova dinastia, de Avis, Ayala o foi da dinastia iniciada pelo irmão e assassino de Pedro Cruel, Henrique Trastâmara. As crônicas de Lopes e Ayala que tematizam a vida dos dois Pedros, tio e sobrinho, dão-nos um perfil de monarca singular e semelhante, mesmo levando em consideração o contraste entre o amor pela justiça do português e os crimes do castelhano. O rei de Portugal teria sido necessário àqueles tempos, porque ele trabalhava sem cessar pela ordem dos negócios do reino, e assim o povo perdoava os seus excessos. Entretanto, é a personalidade excessiva o traço que aproxima Pedro Cru e Pedro Cruel.

Palavras-chave: representação, legitimidade, monarquia medieval, justiça e temperança.
\end{abstract}

\begin{abstract}
We cannot afford to ignore Castille in Fernão Lopes's The Chronicles of Don Pedro. The main source of the Portuguese chronicle writer was Pero Lopes de Ayala's text; however, just like Lopes used to work for the new dynasty, de Avis, Ayala used to work for the dynasty initiated by the brother and murderer of Pedro the Cruel, Henrique Trastâmara. The chronicles of Lopes and Ayala which have been written about the lives of two kings named Pedro, uncle and nephew, give us a profile of kings who were unique but similar, even if we take in consideration the contrast between the Portuguese king's love for justice and the Castillian king's crimes. The role performed by Pedro I as king was essential in those days, for he was responsible for
\end{abstract}

* Professora da PUCPR. Mestra em Literatura Portuguesa (UFRJ) e Doutora em História (UFPR). 
working endlessly for the kingdom's economical and political interests; in this way, the people could forgive his excesses. Nevertheless, the excessive personality is the trait that brings Pedro I and Pedro the Cruel together.

Key-words: representation, legitimacy, medieval monarchy, justice and temperance.

Na História de Portugal, dirigida por José Mattoso, Armindo de Sousa declara que, para os seus contemporâneos, D. Pedro de Portugal (1320-1367) foi "o modo exato de ser rei [naqueles] tempos longínquos e difíceis". ${ }^{1}$ Essa declaração ressalta dois aspectos em concerto: a atuação do monarca e as necessidades ou aspirações de seu momento histórico. A Crônica de D. Pedro de Fernão Lopes é a fonte narrativa mais importante para conhecermos o pai do Mestre de Avis.

O prólogo da Crônica de D. Pedro antecipa elementos da recepção de todo o conteúdo da crônica por parte do leitor. Para Luís de Sousa Rebelo, este é o prólogo mais importante da trilogia porque ele inaugura o ciclo e discute um conceito que não ficará circunscrito ao entendimento do reinado de D. Pedro I. ${ }^{2}$ Elevando a importância dos outros prólogos, o autor ainda afirma que eles são importantes guias de leitura. ${ }^{3}$ Fernão Lopes discute o conceito de justiça, suas implicações práticas para reis e súditos e finalmente a sua relação com a figura do monarca que intitula a obra. Não se deve desprezar o fato de que, antes de se entregar à biografia do monarca, o cronista considere mais importante tratar de uma questão teórica que passa pela precisão do conceito com o qual vai trabalhar. Ele faz questão de assinalar que a justiça é matéria temática de muitos outros textos que têm em comum o fato de propiciar que "[sejam] os maaos castigados e os boons viverem em paz", ${ }^{4}$ e circunscreve a sua noção como "Justiça he huuma virtude, que he chamada toda virtude assi que quallquer que he justo" (p. 3), paralela às leis de Deus (p. 3) e que deve ser guardada por todos (p. 3/4) para a garantia da paz e do sossego (p. 4). Nesse "todos", o cronista inclui reis e súditos, o que confere um alcance extraordinário à virtude. Um rei justo fará leis justas e que serão respeitadas por súditos de igual valor porque elas têm por objetivo "todo bem" (p. 4).

1 SOUSA, Armindo apud MATTOSO, José. História de Portugal. v. 2. Lisboa: Estampa, [s.d.]. p. 489 . 1983. p. 30.

2 REBELO, Luís de Sousa. A concepção de poder em Fernão Lopes. Lisboa: Livros Horizonte, 3 Id.

4 LOPES, Fernão. Crónica de D. Pedro. Porto: Civilização, 1994. p. 3. As próximas citações do texto terão o número da(s) página(s) de cada uma delas registrada(s) entre parênteses logo após o trecho transcrito. 
É preciso lembrar que o poder dos reis ganhou cores diferentes depois do processo de construção da Teocracia Papal vivido de maneira institucional entre os séculos XI e XIII. Os monarcas se afirmaram no espaço compreendido entre os Sumos Pontífices e os Imperadores. "Acuada" em meio a esses dois grandes poderes, a nobreza precisou de um árbitro identificado com ela mesma, e este árbitro foi o rei, cuja atuação se moldou em duas direções, a da justiça e a da administração. Em seu longo processo de centralização do poder, a Igreja promoveu um perfil de monarca dificilmente compatível com a necessidade dos tempos: um rei que devia celebrar a paz, não ser guerreiro e que pudesse conduzir o povo à salvação. Essa elaboração começou ainda no tempo de Carlos Magno, que evidentemente não adotou essa postura. Entretanto, seu filho Luís, o Pio, por exemplo, acabou internalizando esse perfil e se enfraqueceu politicamente.

Pedro I de Portugal herdou as conquistas de poder dos reis medievais anteriores a ele em um momento em que a Teocracia Papal se viu estéril de novas argumentações, momento em que floresceram questionamentos acerca da figura e das atitudes do Papa, feitas no próprio seio da Igreja. Aliás, como observou Le Goff, o Papado viu algo tarde que as suas rusgas contra os imperadores favoreceram especialmente os reis e que os conflitos posteriores entre estes e Roma promoveram a laicização da ideologia política. ${ }^{5}$ Pedro I de Portugal não era membro de uma realeza litúrgica, característica da Alta Idade Média, contribuiu para a construção de um espírito de realeza animado pelo direito, mas não se pode dizer que tenha se preocupado com a manipulação do saber, concebida aqui como intervenção direta nas questões teóricas de alcance moral ou político, como seus descendentes da casa de Avis o fizeram depois. É claro que desde o século XIII já se sente um crescimento da importância do registro escrito para a governação, mas a questão é funcional, diferente do alcance dos textos de D. João I, de D. Duarte ou do Infante Pedro, o Duque de Coimbra. ${ }^{6}$

A Crônica de D. Pedro testemunha um perfil monárquico ímpar, necessário e eficaz. Dentro da obra de Fernão Lopes, Pedro é o mais coerente monarca feudal, ${ }^{7}$ porque seu poder foi extraído de suas prerrogativas feudais, porque ele privilegiou vínculos diretos, exerceu efetiva e pessoalmente o seu

5 LE GOFF, Jacques. A civilização no Ocidente Medieval. v. 1. Lisboa: Estampa, 1983. p. 132.

6 HOMEM, Armando Luís de Carvalho; DUARTE, Luís Miguel; MOTA, Eugénia Pereira. Rei e estado real nos textos legislativos da Idade Média portuguesa. Revista En la España Medieval, Madrid, n. 22, p. $407,1991$. 107.

7 Sobre monarquias feudais, conferir o capítulo homônimo de FOURQUIN, Guy. 1987. p. 99- 
papel de juiz supremo, foi simpático aos nobres ("criador de fidalgos de linhagem" - p. 8) e solicitou o seu dever de conselho. Sua individualização culmina no fato de que, durante o seu reinado, Portugal não conheceu guerras, embora ele até tenha ajudado o seu sobrinho homônimo no conflito contra Aragão.

As leis compreendidas entre os reinados portugueses de Afonso IV e Pedro I, mais especificamente entre os anos 1302 e 1366, realçam três aspectos do ofício régio: a origem divina, a finalidade do poder do monarca e a dimensão ética. Em relação ao segundo aspecto, "como alma, cabeça e coração [do povo], o rei deve guardar o direito, a verdade, a justiça, a paz e a concórdia" ${ }^{8}$ e, em relação ao terceiro aspecto, é importante observar que, apesar de a justiça ser a virtude suprema, a erradicação do pecado também passou a ser muito importante. ${ }^{9}$ A ordenação pessoal dos fatos realizada por Lopes presentifica essas dimensões na Crônica de D. Pedro e revela, acima de tudo, que um rei na Baixa Idade precisava "mostrar serviço", trabalhar - "por non fazer justiça, vem as tempestades, e tribullaçoões sobre o poboo; nom se pode assi dizer deste" (p. 9) - para ser amado pelo seu povo.

Voltando ao Prólogo do texto, o cronista declara que a justiça é mais necessária ao rei. Como a alma que junto ao corpo garante a unidade vivificante do ser, o "prinçipe he lei e regra da justiça com alma" (p. 4) dos reinos. O que Fernão Lopes está a fazer neste caso é recompor a metáfora da lex animata, o rei é a alma do corpo-nação. A voz do rei é também vivificante para a lei que só pode viver por meio dele. Para o cronista, entretanto, de nada adiantariam boas leis sem a perspectiva de sua prática cotidiana e regedora dos "maaos costumes" (p. 5)

Fernão Lopes caracteriza a justiça como a suma virtude, nos termos em que o faz Egídio Romano no De regimine principum. É nesta obra que baseia o essencial da sua reflexão, [trancrevendo-a] em certos passos quase literalmente. ${ }^{10}$

Há uma outra direção menos comum da justiça e que se prende à sua propriedade de conferir "fremusura" (p. 5). Essa propriedade deve levar vantagem em relação à formosura corporal, já que a justiça é mais necessária

8 HOMEM, op. cit., p. 181.

9 Id.

10 REBELO, op. cit., p. 30 
que outra espécie de encanto físico (p. 5) (daí a dupla necessidade de Pedro). Apesar dessa perspectiva, Fernão Lopes encerra a precisão do seu conceito sublinhando a necessidade de se guardar a justiça para todos:

Compre aos Reis seer justiçosos, por a todos seus sogeitos poder viir bem, e a nenhuum o contrairo. Trabalhando que a justiça seja guardada nom soomente aos naturaaes de seu Reino, mas ainda aos de fora delle; por que negada a justiça a alguuma pessoa: grande injuria he feita ao prinçipe e a toda sua terra. (p. 5)

Na "Introdução" da Crônica de D. Pedro, publicada pela editora Livraria Civilização, o Professor Damião Peres demonstra as fontes de Fernão Lopes e o aproveitamento que este fez delas. Segundo o professor, devem-se reconhecer 3 tipos de fontes para a elaboração dessa Crônica: as narrativas, a documentação arquivista e os dados transpostos da tradição. ${ }^{11}$

Em relação ao primeiro tipo, é preciso ser sensível ao fato de o cronista português ter feito um uso bastante extenso do texto de Pero Lopez de Ayala (sobretudo em relação à descrição do sobrinho do monarca português, Pedro, o Cruel, e da Guerra entre Castela e Aragão), o que se repetirá nas outras crônicas. No trabalho com o segundo tipo de fontes - a documentação arquivista, não é possível esquecer que Fernão Lopes teve acesso amplo e irrestrito às fontes reunidas na Torre do Tombo, da qual era inclusive GuardaMor, e que fez uso, por exemplo, de vários diplomas transcritos da Chancelaria de D. Pedro I, das atas das Cortes de 1361, do testamento de D. Pedro, etc. Ao lado dessas fontes, Fernão Lopes certamente colheu dados da tradição, sobretudo em relação à descrição de cenas como a da execução dos assassinos da desafortunada Inês de Castro. Em relação à tradição, muito se deve a ela pela constituição da "lenda" do "rei justiceiro" de que se falará aqui.

Ao lado dos inúmeros pontos incluídos a cada conto sobre D. Pedro, não se pode deixar de observar que eles certamente tiveram por base uma matriz de realidades à qual o personagem correspondeu de certa forma e sem a qual é impossível a formação do mito. ${ }^{12}$ Assim, ao lado da pintura do "justiceiro", Fernão Lopes não se esquece das máculas que o exagero ou mesmo os atos difíceis de serem justificados revelam.

11 PERES, Damião apud LOPES, F. Crônica de D. Pedro. p. 15.

12 Ibid., p. 27. 
A Crônica de D. Pedro é constituída de quarenta e quatro capítulos, acrescidos do prólogo. Todas essas quarenta e cinco partes podem ser compreendidas em três direções: $23 \%$ do texto tratam especificamente da justiça e da impactação dos atos do monarca português em relação a ela (do capítulo 1 até o 10 e o 12); $54 \%$ versam sobre as questões de Castela, do Cruel e da guerra que manteve contra Aragão (capítulos 13, 15 até 26 e 32 até 42) e 14\%, sobre a relação entre D. Pedro e Inês de Castro (27 até 31 e 44). No caso da justiça, é possível atingir um patamar de $27 \%$ se levarmos em consideração o fato de haver capítulos híbridos em relação a seu conteúdo (capítulos 15 e 44). No caso das questões relacionadas a Castela, pode surpreender o fato de ela representar mais da metade do conteúdo do texto, mas neste caso é preciso desconfiar da analogia pura e simples, e tentar perceber como o conteúdo desse segmento pode definir mais amplamente um perfil de monarca necessário àqueles tempos e ao contexto peninsular. Para a confirmação dessa verdade, é necessário comparar as representações feitas por Ayala e Lopes.

Em pouco menos de $10 \%$ da Crônica, Fernão Lopes trata de assuntos como o nascimento do Mestre de Avis ( $1^{\circ}$ capítulo); o translado do corpo da rainha D. Maria, mãe de D. Pedro de Castela ( $2^{\circ}$ capítulo); das cartas de pêsames do rei de Aragão e do Papa por causa da morte de Afonso IV ( $3^{\circ}$ capítulo); da confecção de novas moedas em Portugal ( $11^{\circ}$ capítulo) e das festas que D. Pedro gostava e costumava dar no reino ( $14^{\circ}$ capítulo).

Em relação a essas festas, importa reclamar a contribuição de Helder Macedo, isto porque ela trabalha pela unidade que caracteriza o texto de Lopes. Contrapondo semântica e sensorialmente a dança de D. Pedro à dança macabra, assunto recorrente no século XV, Helder observa que essa cena corresponde a outra, a da investidura de D. João I:

A dança de D. Pedro mostrara o rei em comunhão com os seus súditos; o movimento do povo em volta do Mestre de Avis mostra o desejo de comunhão com um rei que fosse seu. ${ }^{13}$

As festas do pai de D. João I eram momentos em que o rei podia ser tocado - "metiasse na dança com elles" (p. 62) e em que o povo se regozijava ao ver a alegria do seu rei feio, gago e excessivo.

13 MACEDO, H.; GIL, F. Viagens do olhar - retrospecção, visão e profecia no renascimento português. Porto: Campo das Letras, 1998. p. 157. 
$\mathrm{Na}$ verdade, a dança é um movimento de dupla rotação, para si e para os outros. No caráter extensivo, que leva em consideração as interações entre os corpos dos dançarinos, há um desejo de comunhão. A alegria oriunda da fé em um rei justo remonta ao sagrado

alegrem-se os céus, e regozije-se a terra; ressoe o mar e o que ele contém (...), porque [Deus] vem governar a terra. Governará o mundo com justiça, e os povos com fidelidade. ${ }^{14}$

No Ocidente Medieval o toque real pôde operar milagres, incluindo casos na Península Ibérica; aqui ele alivia a alma, pois apazigua os corpos do rei.

A concentração de capítulos que versam sobre a justiça na Crônica de D. Pedro está localizada logo no início desta e a posição eleva ainda mais a importância do traço. É este um dos assuntos mais importantes da crônica, por se prender individualmente ao protagonista. Fernão Lopes não se contenta em ressaltar o amor de $\mathrm{D}$. Pedro à justiça, nem o quanto o seu rigor animava o amor do povo de um ponto de vista laudatório, ele também trabalha com a discussão minuciosa de casos representativos da atuação do monarca. Nestes, não se furta a revelar nome e sobrenome das pessoas envolvidas, o caráter da intervenção de D. Pedro e a solução dada por este.

Um dos aspectos trabalhados pelo cronista com relação à justiça é a preocupação que o monarca português tinha com as leis: "Amava muito de fazer justiça com dereito" (p. 8), com a clareza dos procedimentos que cercavam um processo, como pode ser lido em todo o capítulo 4, e com a rapidez com que D. Pedro exigia que as questões fossem resolvidas, tal qual pode ser averiguado no princípio do capítulo 5. O rei proibiu a atuação dos "vogados" (p. 23) e instituiu, por exemplo, espécies de "juízes itinerantes" na tentativa de evitar favorecimentos na resolução dos casos judiciais nas comarcas. Isto porque o respeito às leis não admitia desigualdade de tratamento dos envolvidos. $\mathrm{O}$ próprio $\mathrm{D}$. Pedro era um monarca que fazia questão de correr a diferentes sítios sempre que ouvia o relato de alguma injustiça.

Fernão Lopes não se furta à exemplificação de casos em que até para si próprio e para os seus D. Pedro não admitia favorecimentos: 
Falando elRei huum dia nos feitos da justiça, disse que (...), e por quanto elle sentia, que o moor agravo que el e seus filhos, e outros alguuns de seu senhorio faziam aos poboos de sua terra, assi em o tomar das viandas por preço mais baixo do que se vendiam, que porem el mandava, que nenhuum de sua casa, (...) que não tomasse galinhas, nem patos (...), salvo compradas aa vontade de seu dono. (p. 26)

A essa determinação segue-se o esclarecimento do preço a ser pago por produtos de consumo e a argumentação em relação à eficácia da pena capital. Segundo D. Pedro, como os homens temiam a morte mais que tudo, as leis deveriam incluir essa pena para evitar o erro.

O rei, os infantes e membros de sua casa deveriam obedecer a essas leis, o que significava que elas incidiam na regulamentação da vida dos grandes e pequenos, dos nascidos no reino, estrangeiros e que deveriam proteger mesmo aqueles que professavam uma outra religião. O capítulo 6 narra o exercício da justiça "sem afeiçom" (p. 29). Mesmo vertendo lágrimas, D. Pedro condena dois escudeiros que ele amava à morte por causa do assassinato de um judeu. As pessoas que argumentavam em defesa dos amigos d'el Rei diziam que a vítima não merecia consideração, mas D. Pedro redargüia: "ElRei ouvindo todos respondia sempre que dos Judeos viinriam depois aos Christaãos" (p. 32).

$\mathrm{Na}$ verdade, ao tratar da pena de morte e da argumentação em favor dela que D. Pedro faz no capítulo 5, é explicitado o receio do exagero no cumprimento das determinações legais. Um caso emblemático desses exageros do monarca português é sem dúvida o de Maria Roussada. Ao ouvir o povo chamá-la dessa maneira, D. Pedro corre a perguntar por que a mulher era conhecida pela alcunha. A explicação de que o marido a havia forçado a dormir com ele antes do casamento despertou a ira justiceira do monarca, que ignorou o fato de o casal viver feliz depois do acontecido e de a união ter gerado frutos. D. Pedro trabalha para que o "sedutor" seja enforcado, como estava determinado: "e elRei por justiça mandouho enforcar, e hia a molher e os filhos carpindo tras elle" (p. 42).

Grande parte da narração dos casos de intervenção de D. Pedro para garantir a justiça se prende a questões de âmbito moral, como regras para casados, para as mulheres, punição a sedutores sejam eles clérigos, almirantes escudeiros e, em especial, até um escudeiro que D. Pedro muito amava, "mais que se deve aqui dizer" (p. 39). No caso do ímpeto do monarca contra as atitudes do bispo do Porto, por exemplo, pode-se dizer que é de natureza 
completamente passional. Ao descobrir que o clérigo dormia com a mulher de um honrado cidadão, D. Pedro arquiteta fazer justiça com as próprias mãos. Manda chamar o bispo, dispensa tanto os seus guardas como os dele, tranca a sala, desveste a si e ao bispo dos trajes que os investiam em seus respectivos papéis sociais, na tentativa clara de aproximá-los no estatuto de homens, e tenta arrancar dele a confissão. Nesse caso, D. Pedro acolhe os pedidos de quem lhe suplicava piedade, e assim "arrefeçeo elRei de sua brava sanha" (p. 35).

A representação levada a efeito na crônica deixa claro que o monarca protagonista não considerava que seus trajes reais investiam-no de um poder maior sobre os homens. No início do capítulo 6, o cronista revela que - "el [o rei] se desvestia de seus reaaes panos, e per as maão açoutava os malfeitores" (p. 29). Pedro I considerava que seu poder não estava ligado ao traje, era-lhe inerente, maior que o poder do bispo. Ao livrar a si e aos outros desses adereços, o monarca poderia estar propondo que não deveria haver diferença entre os homens no trato com a justiça. Entretanto, seu gesto confirma o seu papel de árbitro, já que ele, mesmo sem os panos reais, permanece pleno de direito. A representação de Pedro sugere que aos olhos do cronista seu rei participava de certa forma da glória do sacerdócio. ${ }^{15}$

Na verdade, no princípio do capítulo 7, em que Fernão Lopes narra a sorte do bispo, há uma relação que beira a heresia, quando se recompõe o argumento de D. Pedro de incluir na jurisdição secular o julgamento também dos clérigos. Isto porque D. Pedro observa que Cristo faria a justiça no seu mundo, bem como o monarca português no dele(!). Em contextos diferentes, D. Pedro e Cristo ocupariam um análogo papel na posição mais importante do círculo do poder.

Na composição do perfil do justiceiro, é importante observar que, embora seja o cetro o adereço que compõe a figura tradicional do monarca, no caso de D. Pedro há a substituição desse elemento pelo açoite. Fernão Lopes nos apresenta um rei que andava cotidianamente munido desse novo cetro e fazia uso dele contra

15 "Aos olhos de seus súditos os reis medievais nunca deixaram de parecer participar (mais ou menos vagamente) da glória do sacerdócio”- $\mathrm{BOCH}$, Marc. Os reis taumaturgos. São Paulo: Companhia das Letras, 1993. p. 161.

No político da veneração de São Vicente, uma das alterações mais importantes feitas depois da morte de Nuno Gonçalves foi a reconfiguração do rosto do santo para que pudesse representar as feições do infante D. Afonso (1475-1491). A radiografia da cabeça do santo revelou uma pintura sutilmente diferente e anterior à que conhecemos. Na verdade, depois da morte do príncipe aos dezesseis anos, D. João II pode ter ordenado que o santo retivesse as feições do filho morto tragicamente. São evidentes as semelhanças entre o menino e o santo no dito "Painel do Infante". A preocupação do rei revela a permanência de um ideal que aproximava realeza e sacerdócio, em um período já renascentista. 
os malfeitores sempre que a sua brava sanha se avultava. Essa atitude pasmava os conselheiros do monarca, mas este fazia questão de tomar parte direta na investigação, condução e solução dos processos. O texto da Crônica deixa claro que enquanto reinou D. Pedro não houve crime que ficasse sem a sua solução. No princípio do capítulo 5 , há o emprego de uma dicotomia bastante interessante em relação à atuação do monarca: ele não só era amante da justiça como trabalhava por ela, o que eleva a importância da prática, em detrimento de uma concepção idealizante da matéria.

Outros importantes elementos que se prendem à justiça na Crônica são a economia, a boa administração do tesouro, o enriquecimento e a não dilapidação das heranças. D. Pedro trabalhava para diminuir o custo dos processos e via como questão fundamental a necessidade de as resoluções serem rápidas. Punia com rigor os crimes de recebimento de propinas porque não admitia o enriquecimento ilícito. No capítulo 12, por exemplo, Fernão Lopes narra como o tesouro de D. Pedro cresceu, como o monarca, sem mexer na herança que recebeu do pai, fazia economia nas suas despesas e deixou o reino em boa situação financeira. Esse é um capítulo muito importante, pois eleva a importância da riqueza como garantia da proteção do povo, ou seja, da paz, e antecipa a atuação de D. Fernando, do qual o cronista ainda falaria, como um dilapidador dos tesouros que recebeu. Logo depois do capítulo 12, lê-se a narração de como D. Pedro de Castela juntou o seu tesouro, e a importância de esses textos estarem em seqüência se articula às suas atitudes virtualmente antagônicas.

Em vários momentos, Fernão Lopes coloca na boca de personagens do texto a necessidade de observar a temperança e a importância do acolhimento de diferentes opiniões. O D. Pedro representado por Lopes é um monarca que procura reconhecer os serviços prestados ao reino, a ele, aos de sua casa e antepassados, mas tem muita dificuldade em lidar com o equilíbrio emocional. Na justiça que fez à morte de um judeu causada por escudeiros seus privados, Pedro tem reações díspares, anda de um lado a outro, como insano, chora aludindo ao passado dos seus homens e, no minuto seguinte, investe contra os dois rispidamente, até decidir pelo aniquilamento. No castigo ao bispo, o cronista alude à "brava sanha" do monarca. Seus excessos não são as únicas nódoas da sua personalidade que o cronista desnuda. A possibilidade do juramento em falso no caso do discutido casamento com Inês de Castro, o não acolhimento do sobrinho e das sobrinhas-netas em Portugal depois da invasão de Castela pelo Trastâmara e especialmente a troca dos assassinos de Inês por castelhanos inimigos de Pedro, o Cruel, podem ser apontados como importantes 
elementos desabonadores do perfil de um monarca que trabalhava pela justiça. Não podem ser esquecidas as palavras de Pero Coelho: "elle se saltou emtom comtra elRei em desonestas e feas pallavras, chamamdolhe treedor, fe perjuro, algoz e carniceiro dos homeens" (p. 148). A narração da morte dos assassinos de Inês arquitetada por D. Pedro é o clímax do traço passional da personalidade do monarca português e um dos imaginários construídos pelo cronista mais beneficiados pela longa duração. ${ }^{16}$ Vitória da fome de justiça do monarca ou mérito do inquestionável talento do cronista para criar tipos?

Apesar da explicitação das nódoas da personalidade de D. Pedro, o fechamento da Crônica recupera a idealização do autor de que "diziam as gentes, que taaes dez annos nunca ouve em Purtugal, como estes que reinara elRei Dom Pedro" (p. 202). Esse fechamento traduz a idéia de que excessos havia, mas eles foram "perdoados" em nome de uma série de realizações que acabaram por coroar efetivamente a administração do monarca. Neste caso, a sua relação com a justiça, o modo como trabalhou nela e por ela diretamente foram essenciais para o caráter inigualável dos dez anos em que reinou.

Não é possível ignorar a matéria referente a Castela na Crônica de D. Pedro. Levando em consideração que a solução da crise política que elevou o Mestre de Avis à condição de rei é um dos grandes objetivos do discurso de Fernão Lopes,

a decisão tomada pela rainha [Leonor Teles] de recorrer à intervenção externa impunha que se fizesse a história pregressa das relações políticas de Portugal com Castela. ${ }^{17}$

A fonte principal de Fernão Lopes foi o texto de Ayala, mas é preciso acrescentar que, assim como Fernão Lopes foi funcionário da nova dinastia de Avis, Pero Lopez de Ayala foi também funcionário da dinastia iniciada pelo irmão e assassino do Cruel, Henrique Trastâmara. Depois de narrar a morte de Pedro Cruel e de tentar camuflar a intenção realmente indisfarçável do irmão bastardo, Ayala fez um balanço do reinado do primeiro e revelou entre outras

16 Cinco séculos depois, a força da imagem ainda é capaz de inspirar a prosa portuguesa. No conto “Teorema” (HELDER, Herberto. Teorema. In: MOISÉS, Massaud. O conto português. São Paulo: Cultrix, 1981. p. 368-370.), Herberto atualiza o mito tornando ficcional a voz de Pero Coelho, transformado em narrador do seu destino. Na nova versão, seguindo o princípio de que "quem conta um conto aumenta um ponto", D. Pedro abocanha o coração do novo protagonista da história e ele cresce dentro do rei como uma presença que rivaliza sensualmente com a sua vítima de outrora, "aquela que depois de ser morta foi rainha" (Os Lusíadas, III, 118).

17 REBELO, op. cit., p. 24. 
coisas que o monarca trabalhou muito na guerra, foi cobiçoso de juntar tesouros e que matou muitos homens bons de seu reino; ${ }^{18}$ já quando encerrou o relato da vida do Trastâmara, o mesmo cronista declarou que o seu rei foi muito bem recebedor e honrador das gentes, morreu coberto de ouro e dando conselhos ao seu herdeiro. ${ }^{19}$ Nos dois casos é preciso desconfiar da fonte de Fernão Lopes. As notícias do monarca castelhano registradas na Crônica de D. Pedro correspondem ao lapso temporal do reinado do português.

Em princípio, falar de Pedro Cruel atende aos desejos de um público "ouvinte" (Fernão Lopes emprega o verbo ouvir em várias flexões) de conhecer as circunstâncias da guerra entre Castela e Aragão, como está registrado no final do capítulo XV. Seriam esses ouvintes membros de uma nobreza antiga que ainda tinha muita dificuldade em compreender a autoridade do poder central apoiado em novos segmentos sociais?. ${ }^{20}$ Além disso, porém, abordar esses fatos significa revelar a natureza do envolvimento de Portugal nos negócios com o reino vizinho. Depois da morte de Afonso IV, Pedro toma a iniciativa de confirmar os tratos de amizade e ajuda junto ao sobrinho. Casamentos são acordados e o Cruel consegue o apoio bélico efetivo que não conseguira quando o avô materno era vivo.

O capítulo XVI exemplifica o modo de composição das verdades históricas levadas a cabo pelo cronista português. Enquanto Ayala fragmenta toda a sua crônica para garantir a ordenação cronológica dos fatos, Fernão Lopes reúne e organiza de maneira própria as informações de vários capítulos do castelhano; em três deles, por exemplo, ele cobre um espaço de 7 anos do reinado do Cruel. Do que leu em Ayala, o português conclui que o herdeiro de Afonso XI era "mui luxurioso" (p. 71) e "cobiiçoso do alheo por maa e desordenada maneira" (p. 72). Grande parte da narração da vida do castelhano recuperada por Lopes da crônica de Ayala dá conta das vilanias e atrocidades cometidas pelo Cruel: assassinato de fidalgos; de seus irmãos, filhos bastardos de seu pai e de Leonor de Guzmán (alguns capturados quando pequenos); rapto da sobrinha Leonor dos Leões, ainda bebê; abandono e posterior assassinato de sua legítima esposa, D. Branca de Bourbon; abandono de outra esposa, Joana de Castro; assassinato de primos e de sua tia Leonor de Aragão, etc. Em relação ao assassinato da própria Leonor de Guzmán, o cronista português defende a portuguesa D. Maria, filha de Afonso IV, e esposa de Afonso XI, da

18 AYALA, Pero Lopez. CDH. 4o ano, cap. 7 e 8.

19 Ibid., $14^{\circ}$ ano, cap. 1,2 e 3.

20 REBELO, op. cit., p. 26. 
acusação do próprio Ayala de que teria sido ela a mandante do crime. Fernão Lopes duvida e observa que, mesmo se ela tivesse protagonizado a ação, não poderia tê-la realizado sem o consentimento do filho. Aliás, o cronista castelhano Pero Lopez de Ayala não parece simpatizar com a rainha Maria, pois quando faz registro da sua morte levanta a suspeita de que ela teria sido arquitetada pelo próprio pai, o rei Afonso IV de Portugal, "por quanto nom se pagaua de la fama que oya della". ${ }^{21}$ Sobre isso, só há silêncio em Fernão Lopes.

Pedro, o Cruel, foi o único filho legítimo de Afonso XI e D. Maria, mas teve muitos irmãos, sobretudo frutos da relação de vinte anos entre seu pai e a dama sevilhana Leonor de Guzmán. A rainha portuguesa sabia da predileção do marido e talvez tivesse também o seu preferido, o cavaleiro Martim Afonso Teles, pai de Leonor Teles e que foi para Castela acompanhar a então infanta Maria. Pedro sucedeu o pai aos seis anos de idade e o primeiro desafio que enfrentou foi manter-se vivo. Cresceu alimentado pelo ódio da mãe contra os poderosos bastardos, honrados ainda em vida do pai.

A morte de Afonso XI de Castela foi chorada até pelos mouros ${ }^{22}$ e logo Pedro Cruel confrontou o desejo dos irmãos bastardos e da mãe deles de acompanhar o cortejo fúnebre. Ayala abordou o temor de Leonor de Guzmán de ser presa, mas não levou em consideração a afronta subjacente a Pedro e à rainha Maria. O jovem rei teve de demonstrar desde cedo quem mandava afinal. Uma doença no início de seu reinado motivou até planos de casar a sua mãe e alianças daqueles que, na corte, ora temiam, ora desejavam a morte do rei menino. A preferida de Afonso XI agiu rapidamente e articulou o casamento do Trastâmara com D. Joana Manuel, dama com quem o novo monarca também pensara em se casar. A ameaça dos bastardos, sobretudo de Henrique, marcou o reinado de Pedro Cruel e os problemas entre eles motivaram até mesmo a intervenção de Afonso IV de Portugal, pai da rainha traída.

O que importava para a alta nobreza era o casamento por razões políticas, o amor, portanto, estava fora de questão. Fica evidente que as relações extraconjugais, vividas à margem da política, preenchiam muitas vezes o espaço da afeição, daí as tramas de amor, como a vivida por Pedro e Inês de Castro, por Afonso XI de Castela e Leonor de Guzmán e pelo próprio Pedro, o Cruel, e Maria de Padilha, e a preferência, às vezes problemática do ponto de vista político, pelos bastardos, como Afonso Sanches (filho de D. Dinis) e o Trastâmara (filho de Afonso XI de Castela). A importância desses e de tantos

21 AYALA, Pero Lopez. $C D P, 8^{\circ}$ ano, cap. 2.

22 Ibid., $C D P, 1^{\circ}$ ano, cap. 2. 
outros é tanta que "os descendentes, mesmo em linha ilegítima, de reis, estão em posição de destaque, à frente de nobres de descendência legítima". ${ }^{23}$ Vale lembrar que a nobreza estava ligada à herança paterna exclusivamente e que, em relação à fidelidade, os bastardos levavam vantagem sobre os legítimos na medida que viviam sob a proteção de seus pais, enquanto os outros tinham como objetivo sucedê-los de fato. ${ }^{24} \mathrm{~A}$ fidelidade ao pai morto faz o Trastâmara transladar o corpo de Afonso XI para Córdoba, o sítio de sua preferência registrado no testamento. ${ }^{25}$

O casamento de Pedro e Branca de Bourbon se deveu ao plano de aproximação com essa casa francesa (a noiva era sobrinha do rei João), arquitetado por João Afonso de Albuquerque, tutor do castelhano, mas que foi depois morto a mando do monarca. Na verdade, a influência desse fidalgo português era muito grande, portanto o abandono de $\mathrm{D}$. Branca deve ser lido também como uma ação complexa de Pedro, política e pessoal, no mínimo, para a afirmação da independência dos seus dois corpos, natural e místico; rei e coroa para serem potencializados/libertados em Rei. É evidente que não se trata de justificar ou julgar o ato do monarca, mas sim de tentar compreendê-lo à luz da conjuntura política na qual ele se agitava. O abandono de D. Branca foi aproveitado por uma série de nobres descontentes para engrossarem a oposição ao monarca e o apoio aos bastardos de Afonso XI.

Logo que percebeu que o Cruel tentava se afastar de sua tutela, João Afonso se bandeou para o lado dos bastardos e juntos ensaiaram até uma aproximação com Portugal, oferecendo ao ainda infante Pedro, filho do rei Afonso IV, o reino de Castela. ${ }^{26}$ Orientado pelo pai, o português afastou-se da questão. João Afonso de Albuquerque era um dos nobres mais poderosos ligados a Pedro de Castela; no momento em que sente perder o poder sobre o rei, corre para o lado que lhe sorria com novas possibilidades de sucesso. Sua adesão à causa dos inimigos do seu antigo pupilo pende a balança para o seu novo lado, o que exige do Cruel uma postura rápida: sua escolha foi a perseguição rigorosa.

O caso de João Afonso é emblemático do movimento da fidalguia ibérica, mas conserva particularidades que o sustentam como um caráter individual altamente interessante. Depois da sua morte, seus homens se negaram

23 FELDMANN, S. Amantes e bastardos - as relações conjugais e extraconjugais na alta nobreza portuguesa no final do século XIV e início do século XV. Curitiba: Quatro Ventos, 1999. p. 92.

24 Ibid., p. 133.

25 AYALA, Pero Lopez. $C D H, 6^{\circ}$ ano, cap. 4.

26 Ibid., $C D P, 5^{\circ}$ ano, cap. 8. 
a enterrá-lo e seu corpo era levado a todo lado, participava das reuniões e era "ouvido". Rui Dias Cabeça de Vaca, seu mordomo maior, até "falava" com ele. ${ }^{27}$

O Cruel conheceu a sua amada Maria de Padilha na casa de seu tutor, João Afonso de Albuquerque, e, apesar de ter casado com outra mulher (D. Joana) ainda em vida de D. Branca e de ter se interessado por outras episodicamente, jamais se afastou por muito tempo dos braços da mulher que lhe deu suas três filhas - Beatriz, Constança e Isabel - e um filho - Afonso, morto em tenra idade. Ayala não esconde os sentimentos do rei, o monarca não teve vontade de casar com D. Branca em primeiro lugar por causa de Maria de Padilha, dama "muy fermosa", ${ }^{28}$ a quem ele "amava mucho". ${ }^{29}$ A dama não é ferida pela pena do cronista, que reconhece nela nobreza de caráter, sobretudo quando estão envolvidos os bastardos que o cronista "protege"

ca era buena e de buen seso e nom se pagaua de las cosas que el rei fazia e pesauale mucho de la muerte que era hordenada de dar al maestre [D. Fradique]. ${ }^{30}$

A morte dessa dama foi pranteada em todo o reino por ordem do rei, que mandou trazer o seu corpo para a capela dos reis e depois mandou construir outra, "muy fermosa" 31 para colocar o seu corpo. Pedro Cruel também afirmou que a havia tomado por palavras de presente e que seus filhos deveriam ser tratados por infantes. ${ }^{32}$

Não foram poucas as vezes em que o Cruel tentou aproximar-se de seus irmãos bastardos. É claro que essa aproximação garantia ao monarca a presciência dos caminhos e projetos deles, mas ela colocava-o também em perigo constante. Daí a sensação que temos, ao ler Ayala, de que o monarca castelhano joga com a fidelidade de cada um dos outros filhos de Afonso XI, prometendo honras particulares e segmentando a unidade dos bastardos. Nas vezes em que considerava fundamental confrontá-los, os textos de Ayala e de Fernão Lopes só não conseguem disfarçar as oportunidades em que o Cruel desbarata os irmãos. O seu assassinato, por exemplo, aconteceu em uma emboscada, não em uma luta campal de confronto aberto.

27 AYALA, Pero Lopez. $C D P, 5^{\circ}$ ano, cap. 31.

28 Ibid., $4^{\circ}$ ano, cap. 3.

29 Id.

30 Ibid., $9^{\circ}$ ano,cap. 3.

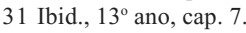

32 Id. 
Fernão Lopes escolhe uma metáfora também comprometida ideologicamente para caracterizar a guerra declarada por Pedro contra Aragão "de pequena faísca se acende grande fogo" (p. 88). Na verdade, o altivo monarca castelhano dificilmente poderia suportar a afronta do capitão aragonês no seu porto. O seu pedido de justiça junto ao monarca do reino vizinho não é atendido e a guerra se acende. A primeira coisa que Pedro IV de Aragão faz é mandar chamar da França os irmãos inimigos do castelhano; não se pode esquecer que o seu reino deu abrigo e honrarias em diversos momentos aos bastardos de Afonso XI, declarados pelo Cruel como seus maiores rivais. A proteção de Pedro IV não poderia ser lida como prova de amizade...

Ayala registrou que Pedro viveu 16 anos de paz, ${ }^{33}$ entretanto não se pode dizer que os viveu tranqüilos, já que as ameaças eram constantes e de todos os lados. Quando se preparava para a guerra contra Aragão, o monarca castelhano recebeu honradamente o fidalgo Pero Carrilho para estar ao seu lado e este não é julgado pelo autor castelhano, nem pelo português, como perjuro, apesar de aproveitar a sua estada em Castela para resgatar das garras de Pedro D. Joana Manuel, esposa do Trastâmara.

O cronista castelhano registra raros comentários pessoais sobre os fatos que narra, mas o mesmo não se pode dizer sobre Fernão Lopes. O narrador da Crônica de D. Pedro tem consciência de que os feitos de Pedro Cruel recuperados por ele podem dar ao leitor a falsa impressão de que ele se compraz no relato de tamanhas atrocidades, assim ele se defende, observando que o monarca castelhano atingiu "notavees pessoas" (p. 103) e que, por isso, não pode deixar de fazer menção. Além de suas apreciações explícitas, a polifonia presente no texto é um dado fundamental para compreender a natureza da recuperação histórica de Fernão Lopes. Sobre isso, o Professor José Gaspar de Oliveira Nascimento tem a dizer que

$\mathrm{Na}$ verdade, o narrador não mostra fatos, ele apenas os diz. E ao dizê-los representa-os subjetivamente. É ele quem dispõe de informações que o leitor ignora. Por meio de sua presciência faz o leitor ver a ação pelos olhos e pela voz das personagens. Em certos momentos, é sua própria voz que se sobressai às demais. É o narrador que seleciona os fatos para relatá-los ao leitor.

A partir das informações que o leitor vai adquirindo sobre o narrador nos meandros da narrativa, pode situá-lo e compreendê-lo. Afinal,

33 AYALA, Pero Lopez. $C D H, 4^{\circ}$ ano, cap. 7 e 8. 
o narrador, como sujeito da enunciação, expande-se em diferentes vozes que dão pistas sobre a imagem que o leitor pode fazer dele. ${ }^{34}$

A demarcação dos diferentes discursos é facilmente reconhecível nas crônicas de Pero Lopez de Ayala. Em Fernão Lopes, há um registro mais "democrático" de vozes ${ }^{35}$ que se interpenetram. A coletividade é representada no discurso, mas não está ausente da crônica do castelhano, como sugerem os estudos que insistem na feição popular presente na crônica portuguesa. Penso que ela merece destaque, mas não se pode menosprezar o registro do choro das mulheres de Córdoba que não queriam ser cativas dos mouros. ${ }^{36}$ As cortes tão representativas tanto em Castela quanto em Portugal revelam as aspirações do concelhio, dos poderes locais mais próximos das necessidades do povo, e beneficiam a amplitude do registro histórico.

Se a guerra contra Aragão começou por motivos fúteis ou justos de um rei que exigiu de outro a justiça contra a afronta de um vassalo ou ainda motivada pelo desejo de expandir territórios firmados em vida dos monarcas antepassados, o que se depreende é que Pedro Cruel se saiu muito bem em vários momentos da contenda, desbaratando inclusive fileiras que contavam com o apoio do Trastâmara. O castelhano pôde contar com o apoio do Príncipe Negro, enquanto Aragão se alinhava à França, o que incluiu a Península Ibérica no contexto da Guerra dos Cem Anos. Jose Terrero observou, ainda em relação à atuação internacional, que o reinado do Cruel não foi frutífero para a Reconquista, ${ }^{37}$ mas não se pode dizer que ele se esquivou da relação com os mouros. Pedro ajudou Mohamed V a recuperar o trono contra o Rei Vermelho, em um dos momentos mais desabonadores do caráter do monarca castelhano representado em Ayala e em Lopes. Mohamed VI prestou vassalagem a Pedro, o que incluiu homenagem e pedido de proteção, e o Cruel fingiu aceitar, para no dia seguinte matá-lo pessoalmente.

A Crônica de D. Pedro registra a ajuda do monarca português ao sobrinho em diversas situações do seu conflito contra Aragão e faz questão de realçar a legalidade desse auxílio, o que ultrapassa Ayala, pois em seu texto sobressai o desamparo ao Cruel. Mesmo quando Henrique Trastâmara é alçado

34 NASCIMENTO, José Gaspar. A lingua portuguesa no século $X V$ : Fernão Lopes. Sorocaba: TCM, 2001.p. 74.

35 Ibid., p. 81.

36 AYALA, Pero Lopez. $C D H, 3$ o ano, cap. 3 e 4.

37 TERRERO, Jose. Historia de España. Barcelona: Ramón Sopen, 1965. p. 169. 
rei e Pedro precisa proteger as filhas e a si mesmo, Fernão Lopes defende o português, deixando claro que o sobrinho não havia feito a exposição dos motivos da viagem de D. Beatriz, sobrinha-neta do Cru, a Portugal. Todas essas explicações visam à resposta ao Príncipe de Gales, já que o Cruel fora se queixar na Inglaterra do desamparo às suas filhas.

Os historiadores do passado mais recuado perscrutam a trajetória do seu próprio tempo. Le Goff costuma observar que as marcas de individualidade que assinalam a diferença dos homens e mulheres da Idade Média contêm a surpreendente possibilidade de reconhecimento. $\mathrm{O}$ seu principal interesse no passado é, portanto, o de compreender o seu tempo presente, o tempo de homens e mulheres do século XXI. Algumas das marcas que formam o perfil do Pedro português e o perfil do Pedro castelhano foram sintetizadas pelos seus epítetos de maneira bastante rica. O primeiro ficou na História como o Cru, que vem do adjetivo latino CRUDUS, A, UM. Em português, além do óbvio "não cozido", cru significa "sem disfarce", "bárbaro, cruel", "áspero, duro", "demasiado livre e chocante". ${ }^{38} \mathrm{O}$ epíteto do segundo monarca tem outra origem, o adjetivo latino CRUDELIS, E, que significa "que gosta de fazer correr sangue, desumano", ${ }^{39}$ este sentido foi desenvolvido em português "que se compraz em fazer mal, em atormentar ou prejudicar (...) severo, rigoroso, tirano". 40

As crônicas de Fernão Lopes e Pero Lopez de Ayala que tematizam a vida dos dois Pedros, tio e sobrinho, dão-nos um perfil de monarca singular e semelhante, mesmo levando em consideração o contraste entre o amor pela justiça do português e os crimes do castelhano. Já foi dito que o primeiro teria sido o rei necessário àqueles tempos e que o povo perdoava os seus excessos, porque ele trabalhava sem cessar pela ordem dos negócios do reino. Pois é justamente a personalidade excessiva o que aproxima os dois monarcas. Pedro era cru no trato com a justiça e o foi singularmente no caso dos assassinos de sua amada: não nos esqueçamos de que ele assistiu à retirada do coração de Pero Coelho pelo peito e de Álvaro Gonçalves pelas costas enquanto almoçava justamente coelho; na verdade, "Fernão Lopes não dissimula o que são actos de crueza substantiva e reserva para eles os mesmos qualificativos que atribui àqueles que cometeu, ou ordenou D. Pedro de Castela". ${ }^{41} \mathrm{O}$ monarca português foi possivelmente perjuro no caso de seu casamento com Inês de Castro; aliás, [s.d.]. p. 405 .

38 FERREIRA, Aurélio. Novo Dicionário da Língua Portuguesa. Rio de Janeiro: Nova Fronteira, 39 TORRINHA, Francisco. Dicionário Latino Português. Porto: Gráficos Reunidos, 1982. p. 215.

40 FERREIRA, op. cit., p. 405.

41 REBELO, op. cit., p.33. 
o cronista declara que a afirmação do monarca de que teria casado pode ter sido inspirada pela que fizera o seu sobrinho no caso com Maria de Padilha. Inovou no uso pessoal e corrente de um instrumento para castigar os criminosos, o açoite, não se negou a ser apenas homem para fazer a justiça (quando se desvencilhava de seus trajes reais) e a dançar entre o povo e realizou o maior rito fúnebre até então visto em Portugal para honrar a transladação do corpo de Inês de Castro. A justiça sem afeição era a necessidade de seu tempo e ele a atendeu.

O outro Pedro foi cruel com os irmãos, afastou a própria mãe e aliada com as suas atitudes, matou vários fidalgos e também foi perjuro, era mau pagador, mas cresceu ciente das preferências do pai, não teve paz, dormia pouco e foi apaixonado por uma mulher que também morreu cedo. Amou a justiça para si mesmo e isto o perdeu. No relato do quarto ano do reinado de Henrique Trastâmara, ainda em vida de Pedro, este recebeu uma carta de um mouro seu amigo que continha predições até das circunstâncias de sua morte. Nesse documento, fica claro que os excessos do monarca ameaçaram um de seus corpos, a corporação ${ }^{42}$ ou a coletividade. Pedro não contava mais com as "peñolas com que afermoses [su] persona real" ${ }^{43}$ e estas "peñolas" são

los omnes grandes en sangre e en linaje, que son sus naturales (...) com las peñolas que destas tales alas se crian en los cuerpos de los rreys, que ennoblesçen mucho sus personas e sus figuras. ${ }^{44}$

Os excessos e desvarios do português foram perdoados porque não ameaçaram o seu corpo "místico", ${ }^{45}$ já os do castelhano custaram-lhe literalmente a vida.

A beleza dos túmulos góticos de D. Pedro I e de Inês de Castro, colocados à direita e à esquerda do transepto da Igreja do Mosteiro de Alcobaça respectivamente, atesta um desejo de permanecer e um certo apego aos valores terrenos em meio a um século que elegeu o túmulo um de seus objetos característicos ${ }^{46}$ Esses monumentos trazem à memória dos passantes as figuras que ali quiseram repousar, na verdade seus restos, até o dia do Juízo Final. A

42 Conferir a teoria dos dois corpos do rei de E. KANTOROWICZ.

43 AYALA, Pero Lopez. $C D H, 3^{\circ}$ ano. p. 274.

44 Id.

45 KANTOROWICZ, E. Os dois corpos do rei: um estudo sobre teologia política medieval. São Paulo: Companhia das Letras, 1998. p. 135-136.

46 DUBY, Georges. 1997. p. 115. 
rosácea do túmulo de Pedro, o Cru, é uma fonte importante para a compreensão de uma mentalidade em transformação, a roda da fortuna simboliza "a instabilidade permanente e o eterno retorno". ${ }^{47}$ A alternância infinita de estados representa uma mudança da própria concepção de tempo, ecos de infinitude, impossíveis de serem refreados desde os averroístas. Aliás, o movimento incessante da roda assinala ainda os ditames da Justiça, ${ }^{48}$ nada mais apropriado ao Justiceiro.

A beleza dos túmulos góticos de D. Pedro I e de Inês de Castro, colocados à direita e à esquerda do transepto da Igreja do Mosteiro de Alcobaça respectivamente, atestam um desejo de permanecer e um certo apego aos valores terrenos em meio a um século que elegeu o túmulo um de seus objetos característicos $^{49}$. Esses monumentos trazem à memória dos passantes as figuras que ali quiseram repousar, na verdade seus restos, até o dia do Juízo Final. Para além da morte, o amor dos dois, carnal e trágico, ganhou definitivamente uma dimensão sagrada. ${ }^{50}$

A rosácea do túmulo de Pedro, o Cru, é uma fonte importante para a compreensão de uma transformação, a roda da fortuna simboliza "a instabilidade permanente e o eterno retorno." ${ }^{51}$ A alternância infinita de estados representa uma mudança da própria concepção de tempo, ecos de infinitude, impossíveis de serem refreados desde os averroístas. Aliás, o movimento incessante da roda assinala ainda os ditames da Justiça ${ }^{52}$, nada mais apropriado ao Justiceiro.

A história de Pedro e Inês de Castro aparece elevada na crônica porque "seu fundamento teem sobre a verdade" (p. 199). A tentativa da sua compreensão transmuta o texto histórico em prosa poética

(...) disserom os antiigos que nenhuum [amor] he tam verdadeiramente achado, como aquel cuja morte nom tira da memoria o gramde espaço do tempo. ${ }^{53}$

47 CHEVAliER, Jean; GHEERBRANT, Alain. Dicionário de símbolos. Rio de Janeiro: José Olympio, 2000. p. 787.

48 Id.

49 DUBY, Georges. A Idade Média - São Paulo: Paz e Terra, 1997. p. 115. Tomo I.

p. 48

50 SARAIVA, António José. O crepúsculo da Idade Média em Portugal. Lisboa: Gradiva, 1998.

51 CHEVAliER, Jean; GHEERBRANT, Alain. Dicionário de símbolos. Rio de Janeiro: José Olympio, 2000. p. 787.

52 Id.

53 Id. 
O cronista não se furta a dizer que diante dela, Pedro I, ainda infante, perdia vista e fala e, longe, "numca çessava de lhe enviar recados" (p. 200). Na verdade, muito se pode afirmar sobre o desfecho dessa história, mas o certo é que a brutalidade com que o assassinato de Inês foi executado nos lembra que a sua morte esteve ligada ao pathos, ao exagero da paixão, não à justiça - "as sentenças eram feitas com pregão público de culpas, o qual não poderia deixar de ser referido nas crónicas" ${ }^{54}$ Daí é difícil crer na declaração feita pelo cronista no princípio do capítulo 27 . Fernão Lopes, que é tão atento às fontes, esconde a sua atrás de um sujeito indeterminado pouco antes de duvidar da veracidade da declaração do rei de que teria se casado com Inês de Castro. "Dizem" (p. $125)^{51}$ que D. Afonso IV mandou averiguar junto ao filho se este havia se casado com a dama Castro, mas como pôde o monarca ter desejos de honrá-la como nora (p. 125) se toda a sua batalha contra o filho foi para que este não tivesse tempo de dar essa honra a Inês? A dúvida do cronista parte de uma premissa também duvidosa para o leitor e atravessa uma lista de honrados fidalgos e clérigos que Fernão Lopes sugere perjuros e manipuladores de bulas papais (capítulo 28).

Quanto à afirmação do monarca de que não dissera antes que havia se casado com Inês por temer o pai, o desfecho da história deu-lhe infelizmente crédito, muito embora encontremos brecha para dar razão também à dúvida do cronista quando nos lembramos de que D. Pedro só se lembrou de publicar o fato muito depois de D. Afonso IV ter morrido.

A representação tumular da tragédia de Inês e Pedro alcança um caráter único quando apreciamos a conjugação das cenas de intimidade do casal, do assassinato, da ascensão ao paraíso e da felicidade que não teve tempo de se concretizar - Inês rainha, sustentada pelos seus algozes. ${ }^{55}$ O Juízo final está representado no túmulo da dama Castro - "os dois amantes obtêm, por direito próprio, um lugar à janela do Paraíso; e aqueles que os contrariaram despenhamse nas goelas do inferno", ${ }^{56}$ mas a espera (ou expectativa) pelo fim do mundo está no túmulo de Pedro. A pedra escreve a nova história do sagrado, o amor entre homem e mulher, apesar das reservas à prática do amor sexual da sociedade cristã ${ }^{57}$ e é "a mais escandalosa afirmação do direito do amor carnal a ter um lugar na escala cristã que abrange este mundo e o outro. É a sacralização do

54 SARAIVA, António José. O crepúsculo da Idade Média em Portugal. Lisboa: Gradiva, 1998.

p. 50 .

55 Ibid., p. 51.

56 Ibid., p. 54.

57 Ibid., p. 55.

História: Questões \& Debates, Curitiba, n. 41, p. 107-129, 2004. Editora UFPR 
desejo" ${ }^{58}$ Poesia em pedra que o texto dos dois cronistas da paixão clandestina não ombreiam em ousadia.

Fernão Lopes, ao ter alinhado os Pedros, pode até ter querido promover o antagonismo, mas registrou um modo de reinar que pode ter resultados efetivos para o bem e para o mal, certamente diferente do modo de ser rei personificado por outro protagonista, o "Mexias de Lixboa", D. João I, e pelo seu filho, D. Duarte, amigo e protetor do cronista português. 


\section{Referências}

BLOCH, Marc. Os reis taumaturgos. São Paulo: Cia. das Letras, 1993.

CHEVALIER, Jean; GHEERBRANT, Alain. Dicionário de símbolos. Rio de Janeiro: J. Olympio, 2000.

DUBY, Georges. A Idade Média - Tomo I. São Paulo: Paz e Terra, 1997.

FELDMANN, Sérgio Alberto. Amantes e bastardos - as relações conjugais e extraconjugais na alta nobreza portuguesa no final do século XIV e início do século XV. Curitiba: Quatro Ventos, 1999.

FERREIRA, Aurélio Buarque de Holanda. Novo Dicionário da Língua Portuguesa. 1. ed. Rio de Janeiro: Nova Fronteira, [s.d.]

FOURQUIN, Guy. Senhorio e feudalidade na Idade Média. Lisboa: Edições 70, 1987. HOMEM, Armando Luís de Carvalho. Rei e estado real nos textos legislativos da Idade Média portuguesa. En la España Medieval, Madrid, n. 22, 1991.

; DUARTE, Luís Miguel; MOTA, Eugénia Pereira da. Percursos da burocracia régia (séculos XIII-XV). In: COLÓQUIO A MEMÓRIA DA NAÇÃO, 1987, Lisboa. Atas. Lisboa, 1991. p. 407.

KANTOROWICZ, Ernst. Os dois corpos do rei: um estudo sobre teologia política medieval. São Paulo: Cia. das Letras, 1998.

LE GOFF, Jacques. A civilização no Ocidente Medieval. Lisboa: Estampa, 1983. 2 v.

LOPES, Fernão. Crónica de D. Pedro I. Porto: Livraria Civilização, 1994.

LOPEZ DE AYALA, Pero. Crónica del rey D. Pedro y del rey D. Henrique su hermano hijos del rey D. Alfonso onceno. Buenos Aires: Secrit/Incipit, 1994/1997 (v. 1 e 2).

MACEDO, Helder; GIL, Fernando. Viagens do olhar - retrospecção, visão e profecia no renascimento português. Porto: Campo das Letras, 1998.

MATTOSO, José (Dir.). História de Portugal. Lisboa: Estampa, [s.d.]. v. 2.

NASCIMENTO, José Gaspar de Oliveira. A língua portuguesa no século $X V$ : Fernão Lopes. Sorocaba: TCM, 2001.

REBELO, Luís de Sousa. A concepção do poder em Fernão Lopes. [S.1.]: Horizonte, 1983.

TERRERO, Jose. Historia de España. Barcelona: Ramón Sopen, 1965.

TORRINHA, Francisco. Dicionário Latino Português. Porto: Gráficos Reunidos, 1982. 